\title{
Sustainable Urban Development and Land Use Management: Wa Municipality in Perspective, Ghana
}

\author{
Daniel Dambeebo ${ }^{1} \&$ Chernor A. Jalloh ${ }^{1}$ \\ ${ }^{1}$ Master's in Infrastructure Planning, University of Stuttgart, Stuttgrt, Germany \\ Correspondence: Daniel Dambeebo, University of Stuttgart, Stuttgart. Allmandring 6, 70569, Germany. Tel: \\ 49-177-917-3122. E-mail: ddambeebo@gmail.com
}

Received: July 23, 2018

doi:10.5539/jsd.v11n5p235
Accepted: August 25, $2018 \quad$ Online Published: September 28, 2018

URL: https://doi.org/10.5539/jsd.v11n5p235

\begin{abstract}
Land use planning is one of the effective ways of achieving overall sustainable physical development especially, in urban areas. Various stakeholders in Ghana such as government agencies are therefore, responsible for the development and enforcement of national and local plans that specifies land areas for residential, industrial, transport and recreational facilities towards achieving sustainable development. Empirical literature within the Wa Municipality is not clear on weather enforcement and/or compliance pose as a challenge to sustainable urban development. The main objective of this study was therefore, to assess the physical development and land use planning guidelines in the Wa Municipality and analyse people compliance for sustainable land management. Both primary and secondary data were used in this study. A questionnaire was used to collect primary data from 173 households in the Wa Municipality. Besides, heads of three institutions responsible for enforcing planning guidelines were interviewed. The results maintained that physical development planning guidelines are there to guide urban development in the Wa Municipality, but enforcement and effective compliance has been weak. Also, demographic and economic variables of the respondents as well as the lack of institutional capacity are the factors responsible for low levels of compliance. The non-compliance with planning guidelines contributes to haphazard physical development. This implies that the existence of clear planning guidelines is a necessary but not sufficient condition for sustainable urban land management. It is therefore, recommended that appropriate intervention through effective education for the general public as well as resource allocation to the enforcement institutions. This will facilitate the achievement of sustainable urban land management in the Wa Municipality.
\end{abstract}

Keywords: land use, sustainable land management, urban planning, urban development

\section{Introduction}

In many developing countries, cities have emerged as engines of economic growth by providing opportunities for education, employment, technological transfer and ready market for industrial goods (Rees, 1992). However, high population growth in urban areas has placed enormous stress on natural resources and imposed "ecological footprints" on urban areas (Rees \& Wackernagel, 1994). Besides, outward expansion of cities results in changes in land use whereby urban residents buy up prime agricultural lands for residential purposes or fail to develop lands in consonance with planning guidelines (Asamoah, 2010). In an attempt to cope with the effects of urbanisation, governments in both developed and developing countries adopt land use policies and strategies that are designed to mitigate the magnitude of urbanisation to manageable levels. This is because urban planning plays an important role in increasing the capacity of cities to cope with population growth (Mutiara et al., 2008).

Land use planning aims at achieving orderly physical development and strives towards evolving a functional and livable environment where individual and common goals can be achieved (Owei et al., 2010). It is also a process of examining different land use options, choosing between them and the making of a physical plan to make the chosen priorities come true. Physical planning may equally involve any deliberate attempts to alter the nature of using land for the purpose of securing aesthetics, convenience, economy, harmony, health and safety of the dwellers of a settlement (Tasantab, 2015; Hermunen, 2004). Effective land use is therefore, considered important in addressing the needs of people and also to control externalities (Ocran, 2015). It has been found that land use is based on the functional dimension of land for different human purposes and economic activities. Typical categories of land use are dwellings, industrial use, transport, recreational use and nature protection areas (Maxwell, 2011). 
In Ghana, there are various stakeholders, governments, NGOs among other agencies that are involved in developmental management of lands in the national, regional and local level (Yakob et al., 2012). The purpose of their stake is that, land use decisions are critical determinants of environmental quality, and it is imperative that land use controls be effectively practiced to combat such problems as pollution, the occupation of hazard-prone areas, the degradation of wetlands and other coastal resources, and the loss of open space and other cultural resources (Willams 2000). Besides, land development agencies are mandated by the state to ensure efficient land administration. Prominent among them include the Lands Commission (LC), the Office of the Administrator of Stool Lands (OASL), and the Town and Country Planning Department (TCPD) (Appiah, 2012). The effectiveness of a plan for development will heavily depend upon the choices made by the local and national government in designing and implementing the plan and the resources devoted to those efforts (Thurman, 2010).

A number of strategies have been taken up to improve the effectiveness of urban planning. Some of them are the ongoing revision of land Acts, creation of urban planning directorates as well as revision of planning budgets (Akola, 2007; Yakob et al. 2012; Owie et al. 2010). For instance, regulatory planning by central government such as protecting natural resources as well as putting in place the needed infrastructure for comfort of society has undergone changes over the years (Kofi, 2004). Besides, the government of Ghana, through the Ghana Poverty Reduction Strategy (GPRS), has initiated measures to address the effects of rapid urban growth on land use. These strategies include ensuring the physical planning of settlement, enforcement of planning regulations and schemes (NDPC, 2005). Land use regulations in Ghana are varied across locations, such as the Kumasi Land Ordinance, 1943 (cap 145), the Land and Native Right Ordinance, 1927 (cap 143), the Akim-Abuakwa (Stool Revenue) Act (No. 28) 1958, the Stool Lands Act, 1960 (Act 27) and the Public Lands Ordinance, 1876 (cap 134) (Ministry of Lands and Forestry, 1999).

There is an increasing recognition that the growth of cities is inevitable and the solution to urban planning problems depends heavily on effective urban planning, infrastructural development and management (Antwi et al., 2014; Asoka et al., 2003). With regards to population for instance, the effects of population growth on urban infrastructure and services shows that there is evidence of haphazard physical development and encroachment to roads, road reserves and way leave (Asoka et al., 2003). The rapid and often unplanned population growth is often associated with population demand that outstrip infrastructure and service capacity and subsequently leading to environmental degradation. In some cases, individual housing preference, cultural traditions and constraints, poor planning and management, relatively low cost of peri-urban land have ensued in increasing physical expansion of cities with low housing densities in Ghana (Cobbinah \& Amoako 2014). This phenomenon characterized Ghanaian cities resulting in poor sustainable land use planning.

Studies have shown that Ghana is still battling with the problem of population to land development. For example, Appiah (2012) found in his study on the management of urban land in Ghana, that the pressures of urbanization and fast growing population of the cities have impacted on land management. According to Antwi et al. (2014) the encroachment of development on wetlands and water ways has been a major challenge for most of Ghana's urban cities as a result of the growth of these cities.

Land use policies have proven as an effective means of achieving sustainable development objectives (Thurman, 2010; Boamah et al., 2012). They are used to regulate human activities and control the provision of recreational centres, education, and commercial activities. The growth of urban populations, however, has exerted great pressure on land resources (Owusu and Asamoah, 2005) thus culminating in non-compliance with land use planning regulations in different ways (Monkkonen and Ronconi, 2013). A study by Thurman on Land Use Regulations and Urban Planning Initiatives, in Development Planning established that, non-compliance with land use planning regulations is often predominant in urban areas taking the form of implementation bottlenecks, such as contradiction of land use policies between government and traditional land owners, and capacity of local government to draft, enact and enforce land use policies (Thurman, 2010). Specifically, despite the existence of laws to regulate development planning in Ghana, urban land-use problems, such as haphazard development, incompatible uses of adjourning lands, inaccessibility of neighbourhoods and insanitary conditions, prevail in the Wa Township (Boamah, 2013; Boamah et al., 2012). Osumanu et al. (2016) maintained that the existence of environmental problems in the Wa Township is a critical case leading to poor land use management. These studies maintained that enormous factors such as income, rent values, facilities available, and nature of residential areas contribute to poor land use planning guidelines with their associated effects of non-compliance. Consequently, the seeking of living spaces by households are subjected to traditional methods, leading to unsustainable urban planning in the Wa Municipality (Osumanu et al., 2016).

The foregoing discussion leads to the following research questions: Are there effective physical development and land use planning guidelines in the Wa Municipality? How are land developers complying with the physical 
development and planning guidelines in the Wa Municipality? Therefore, the objectives of this study are: to assess the physical development and land use planning guidelines in the Wa Municipality and analyse people compliance for sustainable land management.

\section{Review of Related Literature}

\subsection{Compliance with Land Use Planning}

According to Fellmann et al (2005) development occurs when resources of an area or country are brought into full productive use. This includes proper land use planning such as the conversion of vacant land to housing areas and allocation of parcels of land to specific uses with effective compliance (Cobbinah \& Amoako 2014). The Institute for Local Government (2010) maintains that land use is the occupation or use of land or water area for any human activity or any purpose defined in the general plan while guidelines are general statements of policy direction around which specific details may be later established. Land-use planning is a complex process involving development of a land-use which include; statement of land-use issues, goals, and objectives; summary of data collection and analysis; land-classification map; and report describing and indicating appropriate development in areas of special environmental concern (Williams, 2000).

Urban planning plays a very important role in augmenting the capacity of cities to accommodate population growth. A study by Frimpong (2017) identified three main planning regimes in Ghana: the slum areas, the well-planned areas, and the traditional unplanned areas, which falls between the two. These traditional areas are not slums, yet they are also not well planned (Frampong, 2017; Osumanu et al. 2016; Boamah, 2013). The slums are often overpopulated lacking basic services and shelter, the well-planned neighborhoods whether gated or not, have designated boundaries with single family houses with controlled entrances to exclude outsiders. Relating this to Osumanu et al. (2016), some parts of Wa Town can be categorized as a traditional unplanned area. They indicated that there is unavailability of housing facilities while the few housing facilities are in their poor state (Osumanu et al., 2016).

An insight into development control in urban centers of Ghana by Tasantab (2015) reveals that the urban land has expanded tremendously. This coincides with Antwi et al. (2014) report that natural forest lands have been converted into various forms of cultivated lands and settlements. It is reported that residential land has increased from $52 \%$ in 2008 to $55 \%$ in 2014 while farmlands on the other hand have decreased from $30 \%$ in 2008 to $24 \%$ in 2014 (Tasantab, 2015). As a matter of fact, land conversion to residential and other non-agricultural use is more intense in Ghana (Simon et al. 2004).

Research shows that the nature of development of a city or town can impact negatively or positively on its needs and therefore the quality of life of its citizens (Frimpong, 2017; Ocran, 2015; Cobbinah \& Amoako, 2014). Tasantab (2015) concludes that the positive aspects of land use are any deliberate attempts to alter the nature of using land for the purpose of securing aesthetics, convenience, economy, harmony, health and safety of the dwellers of a settlement. A good urban design according to Ocran (2015) will attract human resources to further develop the place and the inhabitants will have self-worth about where they live. He explained that highly educated, skilled as well as high income individuals will be drawn to the quality of life indicator and end up moving into these areas to work. Also, having a good urban layout is closely linked to an improve sanitation. This view is shared by Frimpong (2017), who reported in his study on planning regimes that the notion that some well-planned areas in the Accra such as Airport East, Legon, Trassaco, Cantonment and Labone is because those areas have a proper plan.

On the other hand, the reverse is true where a poorly planned town with bad infrastructure and urban design inhibits drainage and worsens the incidence of diseases and as well attracts people with low levels of human capital (Ocran, 2015). It has been suggested that traditional land-use systems generally do not adequately control the quality, pace or distributional effects of land development and that, even when a plan exists, development activity is too often disorganized (Yachori, 2015). Studies have shown that the lack of good urban design and infrastructures lead to lack of respect, unattractiveness and loss of money for its citizens (Appiah, 2012; Owusu, 2013; Ocran, 2015, Frimpong, 2017).

It has been revealed that urban planning has failed in practice in some developing countries in the world because planning has mostly been overambitious, considering the capabilities of the administrative system to enforce their implementation (Yachori, 2015). In fast growing towns and cities of Ghana, it is a common knowledge that physical development runs faster than planning and as a result of these unplanned physical development, the neighborhoods have poor sanitation issues (UN-Habitat, 2009; Frimpong, 2017). Fusieni (2012) added that Ghanaian city's spatial and demographic growth has been phenomenal, but access to urban infrastructure and services has lagged behind. Cobbinah and Amoako (2014) in their work on urban sprawl and the loss of 
peri-urban land in Kumasi reveals that extension in the metropolis is rapidly consuming fringe rural communities. The rapid rate of urban sprawl in the city leaves no doubt about the increasing conversion of farmlands/agricultural lands in the Kumasi metropolis into residential use without ancillary infrastructure and social services. This suggests that the undesired consequences of land management often happen not only because of lack of planning, but because of inadequacy in planning processes, decisions, policies, and outcome (Abukhater, 2009; UH-Habitat, 2009)

\subsection{Factors Influencing Land Use Compliance}

One might ask why Ghanaian cities appear to be unplanned if effective land use is important to address the needs of the people. Answers to this question show that institutions responsible for land development are challenged with serious shortcomings relating to design of the state regulatory framework, and in particular inadequate institutional capacity for the implementation of state management policies to protect the wide range of interests in land (Sittie, 2006). Land use Act which is an existing law for effective land management tool by developing nations has been difficult to implement (Owei et al., 2010; Yakob, 2012; Mwangi, 2012). Typical example is that of Nigeria where, Owei et al. (2010) describe their Land Use Act (Act 1978) as an Act of deceit; which creates distrust, marred by threats, aggression and litigation between the government and the indigenous community. Furthermore, Akola (2007) reported that environmental problems experienced in Uganda are partly due to the lack of enforcement of the existing urban plans. Same as in Nigeria, where Aluko (2011) discovered that one of the predominant problems to compliance facing Lagos metropolis is that of promoting balance land use that reduce conflict, environmental degradation and leads to efficiency and sustainability.

In the Wa Municipality (Ghana), an analysis of the households living conditions by Osumanu et al. (2016) stipulated that, household seeking living space (land, house, etc.) are subjected to exploitive activities of individual landlords who have no regard for the municipal housing policies and regulation. Not only are the landlords disregarding policies and regulation, but in the context of the unavailability of housing facilities or their poor state, the people do not comply with the municipal by-laws. Lack of participation of the public in the planning process in drafting zoning ordinance, subdivision and growth control measures negatively affects planning process (Asare-Akuffo et al., 2014). The unfortunate thing is that, most people do not obtain the building permits before developing their lands. The few that obtain the development permit are not even supervised to ensure that the development of the lands is in conformity to plans. The result is that, people put up unauthorized structures haphazardly and this led to the development of slums (Yachori, 2017).

The reason for the serious shortcomings relating to design of state regulatory framework, and in particular inadequate institutional capacity for the implementation of state management policies is because less attention is paid to urban planning institutions in Africa (Mwangi, 2012; Akola, 2007). For instances problems such as financial resources, institutional capacity and lack of committed leaders impede mangers in the implementation of land use plan (Yakob et al., 2012). Researchers (e.g Akola, 2007; Yakob, 2012) have acknowledged that the inability of the governments, stakeholders and managers to enforce land use regulations and the master plan have been responsible for the non-compliance to planning guidelines. Akola (2007) found that the Kwamwenge Town Council in Uganda lack human and financial capacities to conduct proper urban planning and management. Aside that he indicated that stakeholders face inadequacy of proper coordination, and also information sharing is very poor because there are no feedback and effective reporting system.

Williams (2000) in his study on environmental planning for sustainable urban development stated that inadequate funding, uncertainty and delay in program administrations, lack of manpower resources and technology are major impediments for management in solving environmental problems. Furthermore, the problems associated with land management include inadequate logistics, poor documentation of transactions, fragmented institutions, inadequate cooperation and coordination among the Land Sector Agencies (LSAs), perceived corruption of some officers of the LSAs and general indiscipline in the land market (Appiah, 2012; Mwangi, 2012). Developing countries such as Kenya and Ghanaian planning system are rife with many institutional weaknesses: outdated planning regulations; conflicting responsibilities and lack of coordination among planning institutions; lack of public participation in the planning process; poor management and lack of technical staff to enforce planning programs. These make it ineffective in controlling the rapid growth of the city (Asare-Akuffo et al., 2014; Mwangi, 2012). In the upper west region of Ghana, Yachori (2017) revealed that Land use planning is highly distorted due to weak legislative framework, poor institutional collaboration, irregular training of staff, and inadequate funding.

\subsection{Effect of Non-Compliance and Lack of Urban Planning}

The present day urban challenges in Ghanaian towns and cities - poor sanitation, inadequate housing, slum 
development, and uncontrolled urban growth (loosely defined as sprawl) and inadequate services like water thus had their roots in the poor performance of spatial planning and non-compliance. On one hand, the unprecedented encroachment on road infrastructure and poorly developed road network are causing rising levels of congestion and traffic jams in the metropolis and on the other hand is the concern of poor (Asare-Akuffo et al., 2014; Cobbinah \& Amoako 2014; Ocran, 2015; Fusieni, 2016; Frimpong, 2017). Yakob et al., (2012) in particular argued that the problem pertaining to non-compliance may discouraged the implementation of sustainable development especially in the housing sector. On that note, Cobbinah and Amoako (2014) re-counted that there is increase congestions, ineffective use of land, and pressure on infrastructural facilities with Kumasi city due to individual housing preferences which deviate from planning regulation. Yakob et al., (2012) also maintained that the issue of non-compliance such as illegal change of land use zoning and conflicts in development plans are among others that affect sustainability in the housing sector in Klang Valley. It is argued that the spate of encroachment on public land-use zonings in Tamale will have negative ramifications for sustainable urban development. First, it will affect social development by restricting access to places for public interaction and socialization. Second, the land tenure changes occurring in the area will breed inequalities by rendering people landless at the expense of a few. Furthermore, transport infrastructure appeared to be inadequate as most roads sections have reached critical capacity, where the volume of traffic flow appeared more than the road networks can handle (Anin et al., 2013).

Concerning sanitation, studies have shown that non-compliance to urban planning guidelines, physical development in Ghana is outstripping drainage networks which pose a serious challenge to the nation (UN-Habitat, 2009; Asare-Akuffo et al. 2014; Ocran, 2015). Asare-Akuffo et al. (2014) maintained that cities are faced with poor sanitation such as worsening waste conditions, however planning officers have in their effort to control this development have not been successful. Similarly, buildings in neighborhood around the cities of Ghana are always on waterways Antwi et al. (2014) and this has culminated into seasonal flooding during the wet season (UN-Habitat, 2009; Frimpong, 2017). Fusieni (2016) noted that the encroachment on open space and reserve/buffer areas (often associated with wetlands, banks of rivers and dams) will likely result in impaired ecological and ecosystem services functions of the urban environment in Tamale, at the time of growing concerns for the impact of cities on climate change. Physical development in these areas also exposes people to natural disasters such as flooding, which not only poses threat to lives and property but also can put pressure on local-government budgets in times of disaster. In addition, Osumanu et al. (2016) revealed that the unavailability of housing facility or their poor state is as a result of the absence of public infrastructure, including access to good roads, water and drainage system. In Ashaiman (Accra) in particular Ocran (2015) indicated that the layout problem in that area has led to diseases and sicknesses such as cholera.

The urban planning has been a development challenge in many regions especially, in developing countries. Specifically, the institutions responsible for the facilitation of land use planning have been proven to be weak; creating opportunity for public misconduct regarding land use by planning standards. This situation, if replicate in the Wa Municipality will not lead to sustainable urban development. It is therefore, imperative to study the factors responsible for compliance with land use planning guidelines for sustainable land management.

\section{Methodology}

\subsection{Study Area}

According to the Ghana Statistical Service (2014), the Wa Municipality is one of the eleven Districts/Municipalities that make up the Upper West Region. The Municipality has its capital also serving as the administrative capital of the entire region. It is also where a lot of land use developments are taking place in comparison with other Districts of the region. The Wa Municipality shares administrative boundaries with Nadowli District to the North, Wa East District to the East and to the West and the South Wa- West District. It lies within latitudes $1^{\circ} 40^{\prime} \mathrm{N}$ to $2^{\circ} 45^{\prime} \mathrm{N}$ and longitudes $9^{\circ} 32^{\prime} \mathrm{W}$ to $10^{\circ} 20^{\prime} \mathrm{W}$ (Figure 1). The Wa Municipality has its capital as Wa. It has a land area of approximately 579.86 square kilometers, which is about $6.4 \%$ of the Region. The study was conducted in Wa, which is also the capital of the Upper West Region; the largest and most developed town in the region. 


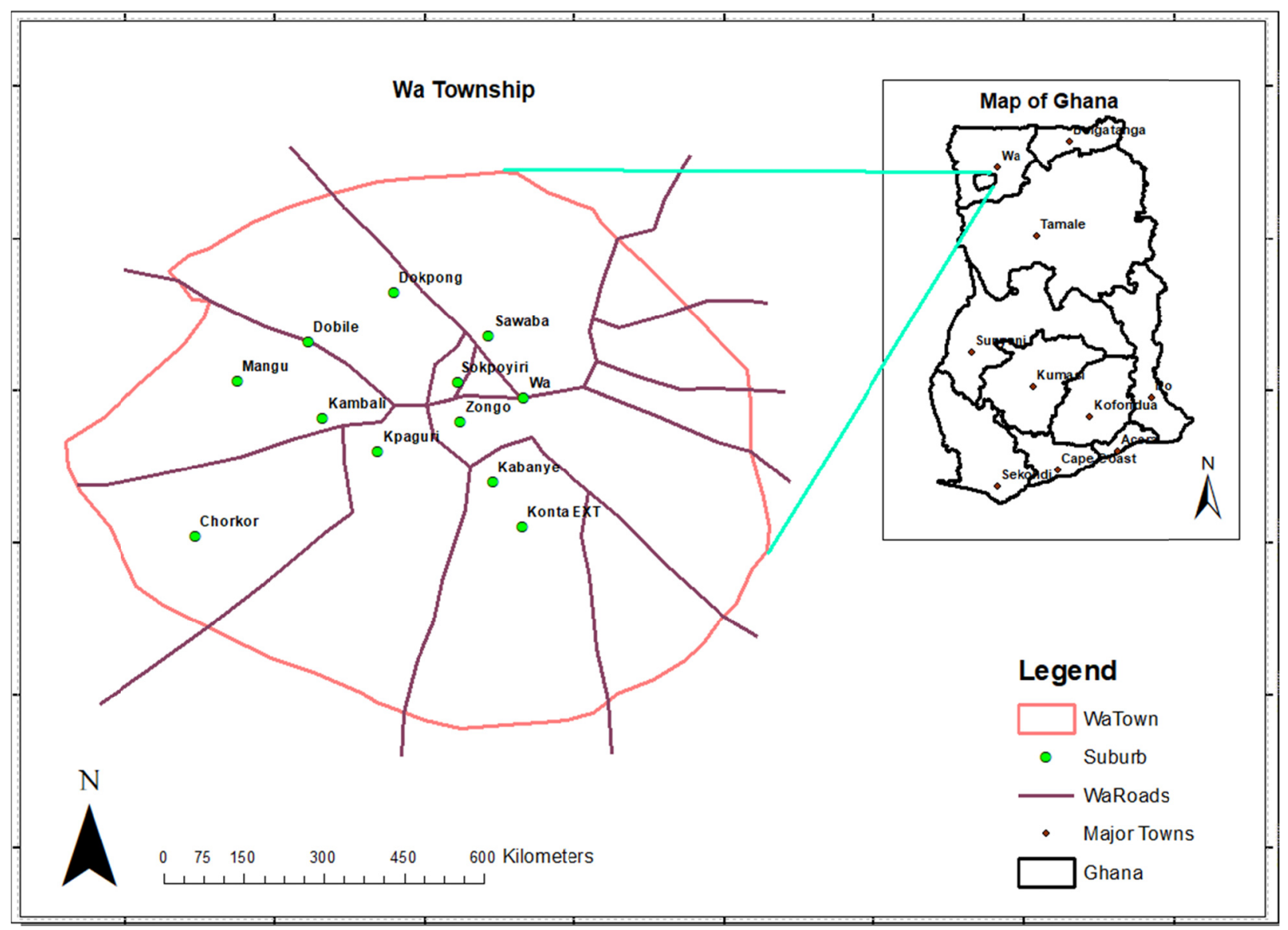

Figure1. Map of study area

Source: Modified from Osumanu et al. (2016).

The Wa Township has several suburbs as shown in Figure 1. Wa Township has three main residential zones: Zone One covered the unplanned residential areas, which includes the Central Business District (CBD). Zone Two is made of the planned suburbs, thus SSNIT Residential Area, Kpaguri Residential Area and Konta Extension. Zone Three comprises the Newly Developing Areas, including the surrounding villages which have been absorbed into the urban agglomeration as a result of urban sprawl. The different residential areas have differences in their land use planning guidelines and hence different levels of compliance for sustainable land management.

\subsection{Research Design}

The study employed a cross sectional survey design which usually produces a 'snapshot' of a population at a particular point in time. A survey has several characteristics and several claimed attractions. Typically, it is used to scan a wide field of issues, populations, programmes etc. in order to measure or describe any generalized features (Cohen et al., 2007). The survey method can be used for descriptive, exploratory, or explanatory research. This method is best suited for studies that have individual people as the unit of analysis (Bhattacherjee, 2012). The relative strength of the survey method informs the choice of it for this study.

\subsection{Population and Sampling}

The population of the study consists of land developers in the Wa Municipality and the institutions responsible for land use planning. The institutions responsible for enforcement of land use planning such as the Wa Municipal Assembly, Town and Country Planning Department and the Survey Department were also considered as part of the population under study.

The sample size for the study was determined using the formula specified by Agresti and Finlay (2009) as: 


$$
\mathrm{n}=\frac{\mathrm{Z}^{2} * \mathrm{P}(1-\mathrm{P})}{\mathrm{M}^{2}}
$$

Where;

$n=$ Required Sample Size

$Z=$ Confidence level at 95\% (standard value of 1.96)

$P=$ Estimated prevalence of respondents' in the population

$M=$ Margin of error at $5 \%$ (standard value of 0.05 )

Evidence from past studies revealed that the proportion of households who have not complied with land use planning guidelines in the Wa Municipality is $87.1 \%$ (Boamah, 2013). This means that the value of $\mathrm{P}$ is 0.871 . Therefore, the desired sample size for the study is:

$$
n=\frac{1.96^{2} * 0.871(1-0.129)}{0.05^{2}}=173
$$

Hence 173 households were selected in the Wa Municipality for investigation into their compliance with physical development and land use planning guidelines. The respondents were selected using a stratified sampling procedure. The whole of the Wa Municipality was stratified into three different residential areas. Zone One covered the unplanned residential areas, which includes the Central Business District (CBD). Zone Two is made of the planned suburbs, thus SSNIT Residential Area, Kpaguri Residential Area and Konta Extension. Zone Three comprises the Newly Developing Areas. The respondents were selected from these residential areas.

\subsection{Data and Analysis}

Data were collected from both primary and secondary sources. The primary data were collected using a questionnaire, interview guide and observation. The questionnaire was used to gather quantitate data from the 173 respondents while the interview guide used to collect qualitative data from institutions responsible for the design and enforcement of land use planning guidelines. The results were coded and entered into the SPSS spreadsheet and analysed using narratives, descriptive and inferential statistics. Besides, the secondary data consist of local plans in a form of maps. The maps provide evidence of proper land use guidelines in the Wa Municipality.

\section{Results and Discussion}

This section presents the results of the study. The main issues discussed include background information of the respondents, the physical development and land use planning guidelines, and the factors influencing compliance with land use planning guidelines.

\subsection{Background Information of Respondents}

This sector presents the results of respondents' background characteristics. The distribution of the variables discussed is shown in Table 1. From the survey, male respondents constitute $85.5 \%$ while the female respondents constitute $14.5 \%$. Besides, the respondents consist of indigenes (37.6\%) and non-indigenes (62.4\%). It was also discovered that the social system of the respondents, values religion and hence all the three dominant religions in Ghana are practiced. From Table 1, 25\% of the sample is Christians, $74 \%$ are Moslems and $0.6 \%$ is Worshipers of African Traditional Religion. Different levels of formal education were observed among the respondents. The results indicate that $22.5 \%$ had no form of formal education, $52.6 \%$ had basic education and $8.7 \%$ had Tertiary level of education. Besides, the main occupations of the respondents include farming, trading, manufacturing/repairs and those serving in the public sector.

Further evidence suggests that the respondents have minimum age of 22, a maximum of 70 , an average age of 40.6 years, this recorded a standard deviation of 7.8. This means that people as young as 22 years have the capacity to own land resources in developing economies such as Ghana. They receive income from multiple sources but often consider one as the main source. Analysis of the income of the respondents revealed that some people ear as low as GHC20.0 while others earn a maximum of GHC4000.0 per month. The average income recorded is GHC1118.62 with a standard deviation of 772.8. This means that land developers in the Wa Municipality has sufficient income to enable them meet the cost of complying with land use planning regulations. 
Table 1. Background information of respondents

\begin{tabular}{|c|c|c|c|c|}
\hline Variable & Frequency & \multicolumn{2}{|c|}{ Percent } & \\
\hline \multicolumn{5}{|l|}{ Gender } \\
\hline Male & 148 & \multicolumn{2}{|c|}{85.5} & \\
\hline Female & 25 & \multicolumn{2}{|c|}{14.5} & \\
\hline Total & 173 & \multicolumn{2}{|c|}{100.0} & \\
\hline \multicolumn{5}{|l|}{ Ethnicity } \\
\hline Indigene & 65 & \multicolumn{2}{|c|}{37.6} & \\
\hline Non-Indigene & 108 & \multicolumn{2}{|c|}{62.4} & \\
\hline Total & 173 & \multicolumn{2}{|c|}{100.0} & \\
\hline \multicolumn{5}{|l|}{ Religion } \\
\hline Christianity & 44 & \multicolumn{2}{|c|}{25.4} & \\
\hline Islam & 128 & \multicolumn{2}{|c|}{74.0} & \\
\hline Traditional & 1 & \multicolumn{2}{|c|}{0.6} & \\
\hline Total & 173 & \multicolumn{2}{|c|}{100.0} & \\
\hline \multicolumn{5}{|l|}{ Level of formal education } \\
\hline No formal education & 39 & \multicolumn{2}{|c|}{22.5} & \\
\hline Basic education & 15 & \multicolumn{2}{|c|}{52.6} & \\
\hline Senior High School & 28 & \multicolumn{2}{|c|}{16.2} & \\
\hline Tertiary & 91 & \multicolumn{2}{|c|}{8.7} & \\
\hline Total & 173 & \multicolumn{2}{|c|}{100.0} & \\
\hline \multicolumn{5}{|l|}{ Main occupation } \\
\hline Farming & 32 & \multicolumn{2}{|c|}{18.5} & \\
\hline Trading & 43 & \multicolumn{2}{|c|}{24.9} & \\
\hline Public Servant & 83 & \multicolumn{2}{|c|}{48.0} & \\
\hline Manufacturing/Repairs & 15 & \multicolumn{2}{|c|}{8.7} & \\
\hline Total & 173 & \multicolumn{2}{|c|}{100.0} & \\
\hline Variable & Min & Max & Mean & Std. Deviation \\
\hline Age & 22 & 70 & 40.62 & 7.84 \\
\hline Monthly income from main occupation & 20.00 & 4000.00 & 1038.67 & 732.79 \\
\hline Monthly Income from minor occupations & 0.00 & 2000.00 & 79.94 & 215.91 \\
\hline Monthly Income & 20.00 & 4000.00 & 1118.62 & 772.83 \\
\hline
\end{tabular}

Source: Field Survey (2018)

The results on respondents' background characteristics imply that land developers in the Wa Municipality have different characteristics and hence can behave differently regarding compliance with land use planning guidelines.

\subsection{Physical Development and Land Use Planning Guidelines in the Wa Municipality}

It was discovered from this study that legislative instruments by an Act of Parliament have been established to guide physical planning and land use in Ghana. The legislative framework further established some institutions to enforce the land use regulations at sub-national levels. This was revealed in an interview with a respondent from the Town and Country Planning Department. The respondents shared the following with the researchers.

"The Town and Country Planning Department operates on statutory frameworks such as the National Building Regulation Act (LI 1630) and Land use and Spatial Planning Act, (Act 925, 1996). The frameworks mandate the department to ensure efficient use of land through proper zoning. Building and development permits are 
therefore, used by the department to ensure conformity of physical development to land use plans" [Interviewee, Staff of Town and Country Planning Department]

The results suggest that there are strong institutions for the regulation of urban development at the national level and this also covers local levels such as the Wa Municipality. Besides, the Town and Country Planning Department has the mandate to zone the land towards sustainable development. To ensure effective compliance, land developers are therefore, required to obtain permit in order to develop their lands. This set the basic standard for a sustainable land management in the Wa Municipality.

Further evidence suggests that some parts of the Wa Municipality have been zoned with clear land uses areas. Figure 2 provide evidence from some layouts with designated residential, commercial and public land use areas.

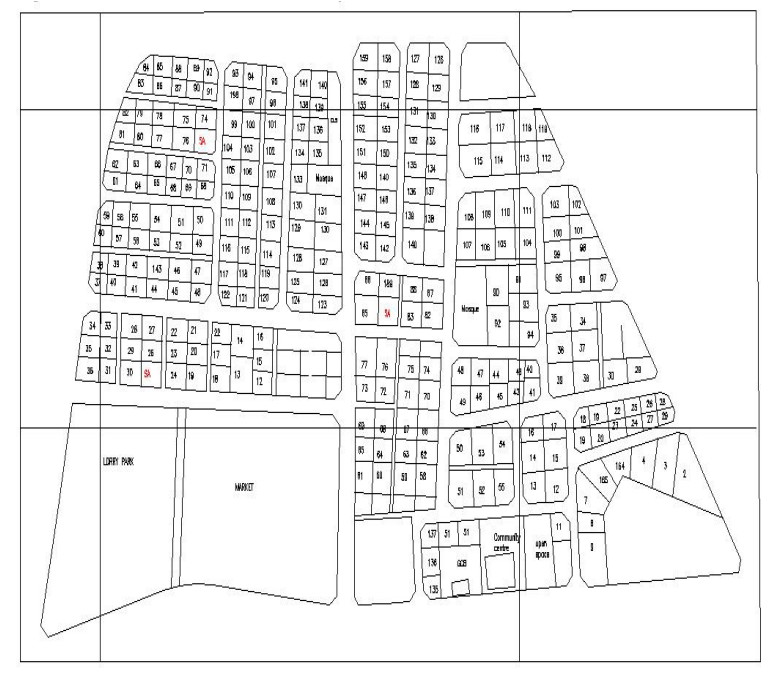

Figure 2a. Central residential area

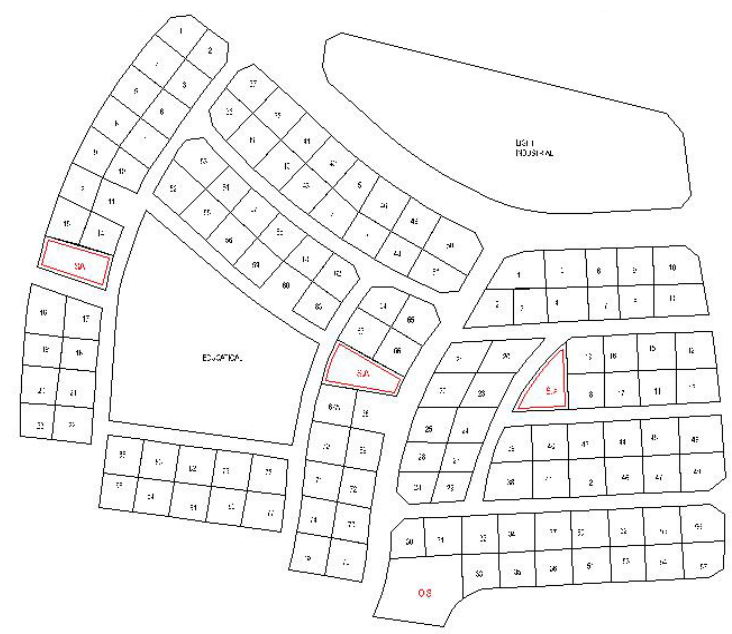

Figure 2c. Napogbakole extension

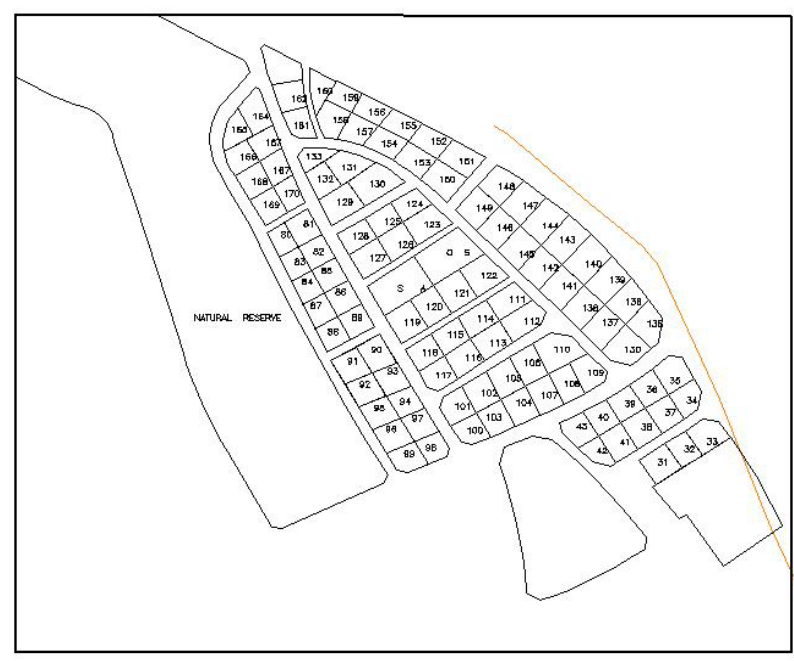

Figure 2b. Mangu residential area
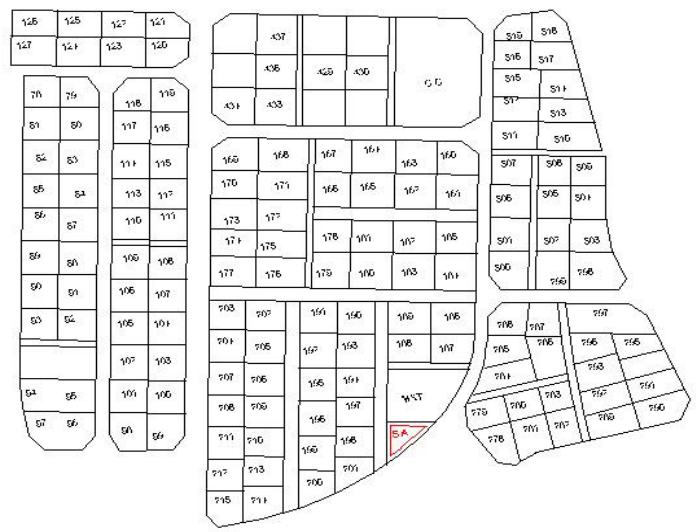

Figure 2d. Sombo residential area

Figure 2. Evidence of Layouts of some portions of the Wa Municipality

Source: Town and Country Planning Department (2018)

The evidence in Figure 2 implies that the layout of the Wa Municipality has areas for residential facilities, markets, sanitary areas, roads, schools and other public land use areas. This means that haphazard development in the Wa Municipality as claimed by Boamah, (2013) and Osumanu et al. (2016) is not because of the absence of regulation or planning guidelines. This means that other socio-economic factors would be responsible for unsustainable land management. 


\subsection{Factors That Influence Compliance with Land Use Planning Guidelines}

Some demographic and economic variables were found to have influence on compliance with land use planning guidelines. The factors were identified using Chi-square test of independence. They include income, ethnicity, development of a site plan, and occupation. The variable categories, Pearson Chi-square value, degree of freedom (df) and significance (P-value) are shown in Table 2.

Table 2. Factors influencing compliance with land use planning guidelines

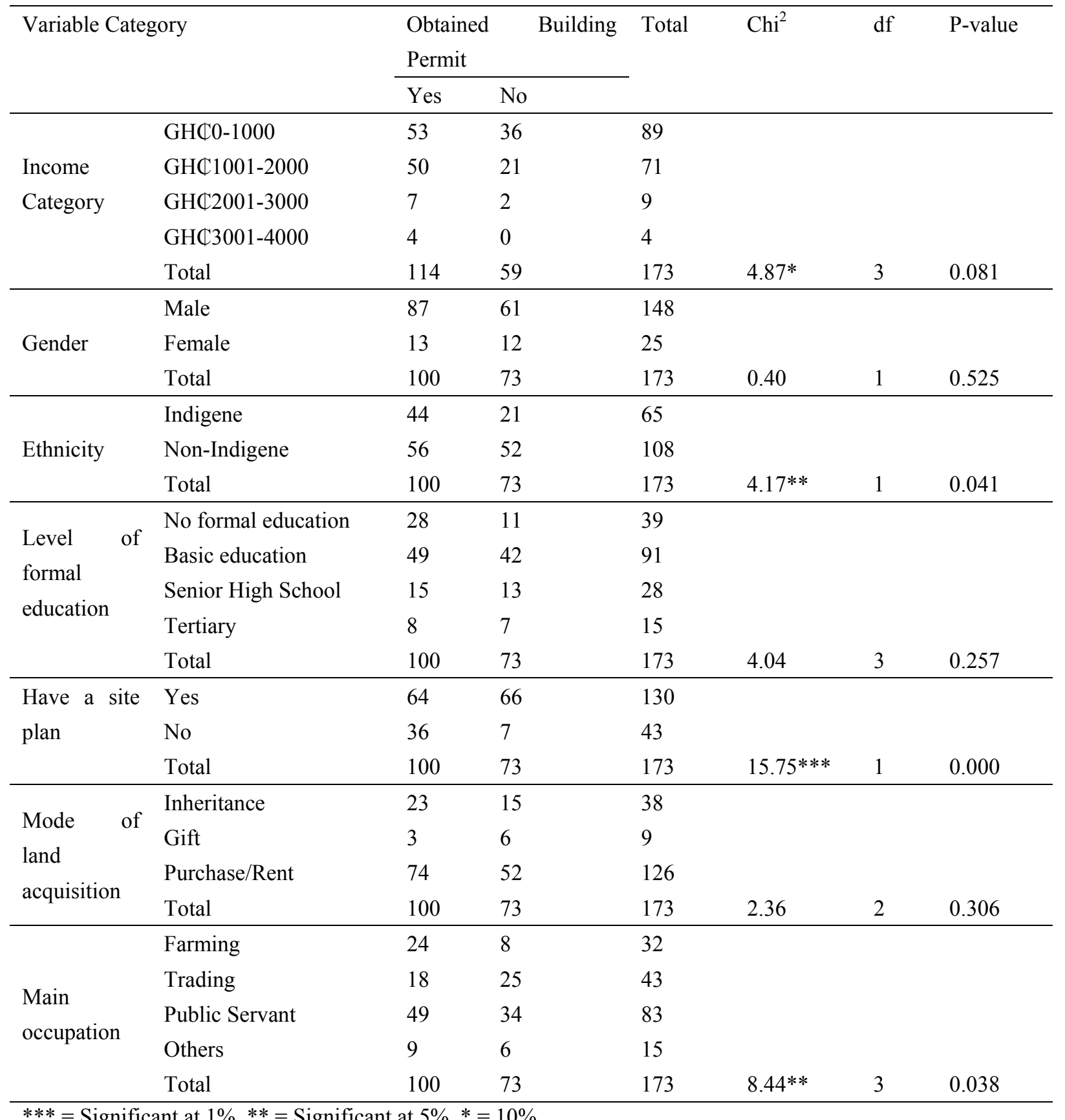

$* * *=$ Significant at $1 \%, * *=$ Significant at $5 \%, *=10 \%$

Source: Field Survey (2018)

The results in Table 2 revealed that income of the respondent and obtaining of building permit has a strong influence on each other. This is due to the fact that the Pearson Chi-square value (4.87) was found to be significant at $10 \%$ (P-value $<0.1$ ). From the table, high income earners were found to have complied with land 
use regulations and were given permit to develop their lands. Hence there is enough evidence to reject the independence of income and obtaining of building permit to develop one land.

The results further indicate that ethnicity plays a significant role in complying with the physical development and planning guidelines. From Table 2, the chi-square value of 4.17 was reported which is significant at $5 \%$ (P-value $<0.05)$. This means that there is enough evidence that respondent ethnicity is independent on compliance with land use regulations. From the results, respondents who are non-indigenes were found to have complied more than those that are indigenes.

The results also indicate that people who developed site plans for their lands were found to have permits to further develop their land than those who do not acquire site plans at all. From Table 2, the Chi-square test value is 15.75 and was found to be significant at $1 \%$ (P-value $<0.01)$. This means that there is enough evidence to reject the independence of acquisition of site plan and obtaining of permit to develop one land. Since many of those who have acquire site plans have also obtained permits, it can be concluded that development of site plan has a positive influence on obtaining of building permit.

Finally, the respondents were found to have been engaged in different occupations. The findings in Table 2 suggest that there are variations in the number of people from different occupations who have obtained building permits. The chi-square analysis provides a test value of 8.44 which is significant at $5 \%(\mathrm{P}$-value $<0.05)$. This provides enough evidence to reject the independence of occupation and obtaining of building permit. The frequencies suggest that people who are in the public service often comply more than those in other occupations.

\subsection{Reasons for not Complying with Physical Development and Planning Guidelines}

The results revealed that some challenges confront institutions in enforcing compliance with physical development and planning guidelines in The Wa Municipality. An interview with a respondent from the Wa Municipal Assembly revealed that the attitude of landlords contributes to the challenges facing institutions in enforcing physical development planning guidelines. The caption below was noted during the interaction:

Land developers in the Wa Municipality are aware that the Lands commission, Town and Country Planning Department, the Survey Departments, and the Wa Municipality are the key institutions responsible for the enforcement of land use planning regulations. However, the level of bureaucracy and largely the attitude of landlords have made it difficult to achieve high levels of compliance. Some people despite the challenges associated with the system have been able to comply while others just refuse to follow the necessary procedures thus making the work of the Assembly, in particular, very difficult.

The results suggest that land developers deliberately refuse to follow the necessary procedures in obtaining their lands or permits to develop their lands. This means that the institutions are under resourced and hence lack the capacity to enforce compliance with basic regulations. Therefore, there will be haphazard development despite the availability of well-planned layouts to guide physical development. This observation confirms the claim of Owei et al. (2010), Yakob (2012) and Mwangi (2012) that sustainable land management tools in the developing world have been difficult to implement. This is the case in Nigeria which according to Owei et al. (2010) that the main institutional framework for land management has been considered as a deceit because of lack of capacity for its enforcement.

Further evidence suggests that attitude of landlords alone is not the cause of non-compliance or challenges with enforcement but the fact that some of the regulatory institutions have failed to perform their required duties. The results point out that the Wa Municipal Assembly often fails to procure lands appropriately from landlords for further zoning and this allow the landlords to develop their lands with little or no planning guidelines or regulation. This opinion was recorded in an interview with a respondent from the Town and Country Planning Department.

Achieving orderly development and well planned Municipality does not entirely depend on effective enforcement of plans or the different control mechanisms like zoning and permit systems adopted in in the Municipality, but also the failure of the Assembly to procure and protect parcels of lands for public places has resulted in encroachment" [Interviewee, Staff of Town and Country Planning Department].

In related literature, Mwangi (2012) argue that less attention is paid to urban planning institutions in Africa. This is the case of the Wa Municipality where the Muncipal Assembly does not have the capacity to procure parcels of land for further development according to planning guidelines. Similar findings were reported by Akola (2007) in Uganda where the Uganda Town Council lacks the needed financial capacity to conduct proper planning and management.

The results indicate that the main issue of non-compliance with physical development planning guidelines is 
conflicts among land lords. This arises where non-compliers put up inappropriate structures on their lands that inconvenience others. Besides, the encroachment of public lands also means that people will not have access to some facilities such as roads, markets, and schools because places designated for such services have been used wrongly by people who fail to comply with development planning guidelines. These findings agree with the results of Asare-Akuffo et al. (2014) Fusieni (2016) and Frimpong (2017) that unprecedented encroachment on road infrastructure and poorly developed road network are causing rising levels of congestion and traffic jams in urban areas. Moreover, Yakob et al., (2012) in particular argued that the problem pertaining to non-compliance may discouraged the implementation of sustainable development especially in the housing sector. This means that the Wa Municipality will have challenges in maintaining sustainable land management and physical development. Hence, the effects of non-compliance as outlined by empirical literature are not different from what has been observed in the Wa Municipality.

From the perspective of the Town and Country planning Department, one main effect of non-compliance with physical development planning guidelines is unplanned development leading to slums. The respondent shared this with the researcher during an interview:

"When people fail to comply with existing physical development planning guidelines, their activities lead to slum development. Sometimes such structures are pulled down, which attract cost to both the landlord and the municipal assembly".

The results imply that non-compliance with physical development planning guidelines affect both individuals and institutions such as those facilitating compliance with the guidelines. The process of forcing people to comply introduces financial cost to both the victims and the municipal assembly as well. The pulling down of structures is a way to maintain sustainable development despite the cost associated with it. In the view of Antwi et al. (2014), UN-Habitat (2009) and Frimpong (2017), buildings in neighborhood around the cities of Ghana are always on waterways culminated into seasonal flooding during the wet season. This means that such land developers have often failed to comply with the necessary regulations such as obtaining of permit to develop one land. In the Wa Municipality, efforts are being made to pull down such structures as a way of ensuring sustainable urban development.

\section{Conclusion and Recommendations}

Many economies have taken steps to ensure sustainable land management through the establishment of institutions and physical development planning guidelines to control haphazard development. Ghana has complied with this fundamental process through the establishment of land use planning guidelines and institutions to enforce compliance. However, the Wa Municipality has not yet achieved sustainable urban land management despite the existence of such institutions. Institutional weakness, socio-demographic and economic factors are partly the reasons for non-compliance with land use planning guidelines. This implies that the existence of clear planning guidelines is a necessary but not sufficient condition for sustainable urban land management. It is therefore, recommended that appropriate intervention through effective education for the general public. Moreover, resource allocation to the enforcement institutions will equally facilitates the achievement of sustainable urban land management in the Wa Municipality.

Additionally, further studies are strongly recommended to focus on the Current regime of land governance in the country, institutional governance and land management and finally, how traditional authorities could be involved in zoning and land use planning within the Wa Municipality.

\section{References}

Abukhater, A. (2009). Rethinking planning theory and practice: A glimmer of light for prospects of integrated planning to combat complex urban realities. Theoretical and Empirical Researches in Urban Management.

Akola, J. (2007). Urban planning as a tool of Environmental Management in Kamwenge Town-Western Uganda. Master's Programme in Urban Management and Development (October 2006 - September 2007).

Aluko, O. (2011). Development Control in Lagos State: An Assessment of Public Compliance to Space Standards for Urban Development. International Multidisciplinary Journal, Ethiopia. Indexed African Journals, 5(5), 169-184.

Anin, E. K., Annan, J., \& Alexander, O. F. (2013). Assessing the causes of urban transportation challenges in the Kumasi Metropolis of Ghana. American Based Research Journal, 2(6).

Antwi, E. K. et al. (2014). Land Use and Landscape Structural Changes in the Ecoregions of Ghana. Journal of Disaster Research, 9(4). https://doi.org/10.20965/jdr.2014.p0452 
Appiah, W. K. (2012). The management of urban land in Ghana: the case of Accra and Kumasi metropolitan areas. Kwame Nkrumah University of Science and Technology, Ghana.

Asare-Akuffo, F., Appiah-Opoku, S., Weber, J., \& Koti, F. (2014). Evaluating the Effectiveness of Urban Planning and Administration in Taming Urban Sprawl: A Case of Kumasi-Ghana. The University of Alabama.

Asoka, G. W. N., Thuo, A. D. M., \& Bunyasi, M. M. (2013) Effects of Population Growth on Urban Infrastructure and Services: A Case of Eastleigh Neighbourhood Nairobi, Kenya. Journal of Anthropology \& Archaeology, 1(1), 41-56.

Boamah, N. A. (2013). Land Use Planning And Housing Situation In The Wa And Offinso South Municipalities, Ghana. Ethiopian Journal of Environmental Studies and Management, 4(6). https://doi.org/10.4314/ejesm.v6i4.13

Cobbinah, P. B., \& Amoako, C. (2014). Urban Sprawl and the Loss of Peri-Urban Land in Kumasi, Ghana. World Academy of Science, Engineering and Technology. International Journal of Humanities and Social Sciences, $8(1)$.

Fellmann, J. D., Getis, A., \& Getis, J. (2005). Human Geography, Landscapes of Human Activities (8th ed.). McGraw-Hill, New York. 355.

Frimpong, J. (2017). Planning Regimes in Accra, Ghana. University of Waterloo, Ontario, Canada.

Fuseini, I (2016). Urban governance and spatial planning for sustainable urban development in Tamale, Ghana. Stellenbosch University.

Hermunen, T. (2004). Land Use Policy in Kenya - Experiences from Taita Taveta District. A Thesis submitted to Department of Geography for the Degree of Master of Planning Geography, University of Helsinki, Finland.

Kleemann, J., Inkooma, J. N., Thiel, M., Shankar, S., Lautenbach, S., \& Fürst, C. (2017). Peri-urban land use pattern and its relation to land use planning in Ghana, West Africa. Landscape Urban Plan. https://doi.org/10.1016/j.landurbplan.2017.02.004

Kofi, A. S. (2004). The need for changes in Urban Planning, Case study of Accra capital city of Ghana. 40th ISoCaRP Congress 2004.

Maxwell, A. (2011). Dynamics of Land Use Planning and Its Effects on Socio-Economic Development. Case Study of Sunyani Municipality and Odumasi in the Brong Ahafo Region. Kwame Nkrumah University of Science and Technology.

Mwangi, M. J. (2012). Analysis of technical skills of local authority staff in urban land use planning units in central region, Kenya. University of Nairobi.

Ocran, M. (2014). An Investigation into City Planning and the Possible Implication for Ghana's Development: Tema and Ashaiman Compared. Ashesi University College.

Osumanu, I. K., Kosoe, E. A., \& Dapilah, F. (2016). Residential housing in Ghana's low-income urban areas: An analysis of households living conditions in the Wa Municipality. Journal of Geography and Regional Planning, 9(7), 139-153.

Owei, O. B., Obinna, V. C., \& Ede, P. N. (2010). The Challenges of Sustainable Land Use Planning in Nigerian Cities: The Case of Port Harcourt. 46th ISOCARP Congress.

Owusu G. (2013). Coping with Urban Sprawl: A Critical Discussion of the Urban Containment Strategy in a Developing Country City, Accra. Planum. The Journal of Urbanism.

Simon, D., McGregor, D., \& Nsiah-Gyabaah, K. (2004). The changing urban-rural interface of African cities: Definitional issues and an application to Kumasi, Ghana. Environment \& Urbanization, 16(2).

Sittie R. (2006). Land Title Registration - The Ghanaian Experience, Shaping the Change XXIIIFIG Congress, Munich, Germany, October $8-13$.

Tasantab, J. C. (2015). An Insight into Development Control in Urban Centres of Ghana; A Study Of Sekondi-Takoradi. Kwame Nkrumah University of Science and Technology.

The Institute for Local Government. (2010). Understanding the Basics of Land Use and Planning: Glossary of Land Use and Planning Terms. 1400 K Street, Suite 205, Sacramento, California 95814. 
Thurman, K. G. (2010). Land Use Regulations and Urban Planning Initiatives in Accra, Ghana. PLAN A6211.001. Advanced Issues, In Development Planning.

UN-HABITAT. (2009). Ghana: Accra Urban Profile. United Nations Human Settlements Programme.

Williams, R. A. (2000). Environmental planning for sustainable urban development. Caribbean Water and Wastewater Association 9th Annual Conference \& Exhibition at Chaguaramas, Trinidad, 2 - 6.

Yachori, B. (2017). Urban planning capacity development's response to emerging issues of urbanization in the Wa and Lawra townships of Upper West Region. University for Development Studies.

Yakob, H., Yusof, F., \& Hamdan, H. (2012). Land Use Regulations towards a Sustainable Urban Housing: Klang Valley conurbation. ASIA Pacific International Conference on Environment-Behaviour Studies Mercure Le Sphinx Cairo Hotel, Giza, Egypt. Social and Behavioral Sciences, 68, 578-589.

\section{Copyrights}

Copyright for this article is retained by the author(s), with first publication rights granted to the journal.

This is an open-access article distributed under the terms and conditions of the Creative Commons Attribution license (http://creativecommons.org/licenses/by/4.0/). 